\title{
Mutarotation, Hydrolysis, and Structure of D-Galactosylamines
}

\author{
Harriet L. Frush and Horace S. Isbell
}

\begin{abstract}
Of the two previously described galactosylamines, one has been shown to be a mixture. A pure compound has now been isolated from it, thus making available for the first time two pure modifications of a glycosylamine. The structure and properties of these compounds and of certain derivatives have been determined. The new substances constitute a group of reference compounds useful for the assignment of structure in this field. The mutarotation and hydrolysis of the two galactosylamines were studied and found to be in harmony with mechanisms previously advanced by us.
\end{abstract}

\section{Introduction}

Reaction of ammonia or suitable amines with sugars produces glycosylamines by replacement of one amino hydrogen with a glycosyl group. The compounds are of interest, because, like many biologically important substances such as nucleic acids and certain coenzymes, they contain an $N$-glycosyl linkage. In a previous publication $[1],{ }^{1}$ it was shown that in solution L-arabinosylamine, I, undergoes a mutarotation reaction that is followed or accompanied by hydrolysis of the amino group. The mutarotation is strongly catalyzed by acids; the hydrolysis, like certain enzyme reactions, is rapid only in the $\mathrm{pH}$ range 3 to 7 . Mechanisms were advanced to account for these unusual properties, through the intermediate formation of the imonium ion $-\mathrm{C}=\stackrel{+}{=} \mathrm{H}_{2}$. Hydrolysis was conceived as involving combination of the imonium ion with hydroxyl ion, and decomposition of the resulting aldehyde ammonia. Lack of reaction in highly acid solution was ascribed to low hydroxyl ion concentration, and lack of reaction in alkaline solution to low imonium ion concentration. To provide additional support for the mechanisms, a study has now been made of the D-galactosylamines.

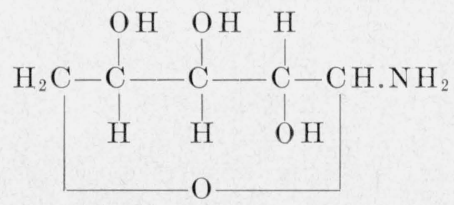

L-Arabinosylamine.

\section{Preparation and Structure of the Galactosylamines}

By treatment of galactose with ammonia and methanol, de Bruyn and Van Leent [2] obtained two galactosylamines of unknown structure. One of the amines had an initial specific rotation of $+87^{\circ}$, and contained a mole of loosely bound ammonia; the other had an initial specific rotation of $+64^{\circ}$, and

\footnotetext{
1 Figures in brackets indicate the literature references at the end of this paper.
}

was ammonia free. These compounds have now been prepared and their structures determined. By repeated recrystallization of the ammonia complex, the initial rotation was raised from $+87^{\circ}$ to $+138^{\circ}$. Inasmuch as the optical rotation could not be further increased, it is believed that this material is a pure modification of the galactosylamine. Preparation of the amonia-free form of galactosylamine by a number of methods, and repeated recrystallization of the product, gave a substance having an initial specific rotation of $+62^{\circ}$ in comparison with the value of $+64^{\circ}$ reported in [2]. The two modifications of galactosylamine were acetylated, and yielded crystalline pentaacetates, which differed in properties. By deacetylation of the pentaacetates, the corresponding crystalline Nacetylgalactosylamines were obtained, and the latter compounds were shown by periodate oxidation and study of the dialdehydes to be an alpha-beta pyranose pair. Since mild conditions of acetylation and deacetylation were employed, it appears reasonably certain that the parent galactosylamines as well as the corresponding pentaacetates are also alpha-beta pyranose pairs. The mutarotation and hydrolysis of the two galactosylamines have been studied, and found to be in harmony with the mechanisms previously advanced.

In accordance with convention, the more dextrorotatory amine II (known in the form of the ammonia complex) is designated alpha; the less dextrorotatory amine III is designated beta, even though it does not exhibit normal mutarotation. The lack of mutarotation might suggest that the compound is an isomeric mixture. Such a mixture, however, on mild acetylation, would have yielded a mixed acetate. The fact that a high yield of a nearly pure acetate was obtained supports the conclusion that the parent glycosylamine is a single modification and that the equilibrium mixture for D-galactosylamine consists almost entirely of the beta form.

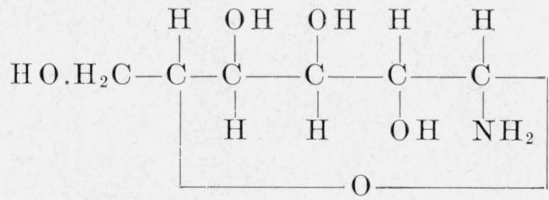




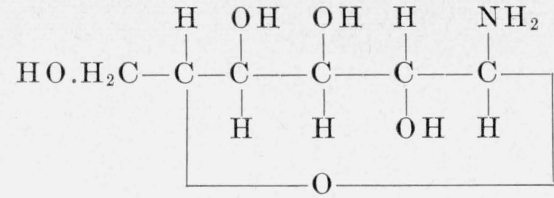

$\beta$-D-Galactopyranosylamine.

\section{Mutarotation of $\alpha$-D-Galactosylamine Ammonia Complex and $\beta$-D-Galactosyl- amine}

The changes that occur when $\alpha$-D-galactosylamine ammonia complex is dissolved in water are given in table 1 . The behavior of the substance resembles that of $\mathrm{L}$-arabinosylamine in that the optical rotation, $[\alpha]_{D}^{20}$, drops to a minimum and then rises slowly. The first change may be ascribed to the mutarotation reaction and the second to hydrolysis. Table 2 gives a comparison of the behavior of $\alpha$-Dgalactosylamine ammonia complex and of $\beta$-Dgalactosylamine in water and in aqueous $2.5 \mathrm{~N} \mathrm{HCl}$. At the time of the earliest reading in acid solution the

TABLE 1. Mutarotation of $\alpha$-D-galactosylamine ${ }^{\text {s }}$

[0.5 g $\alpha$-D-galactosylamine ammonia complex dissolved in water to give a volume of $25 \mathrm{ml}$ at $20^{\circ} \mathrm{C}$ ]

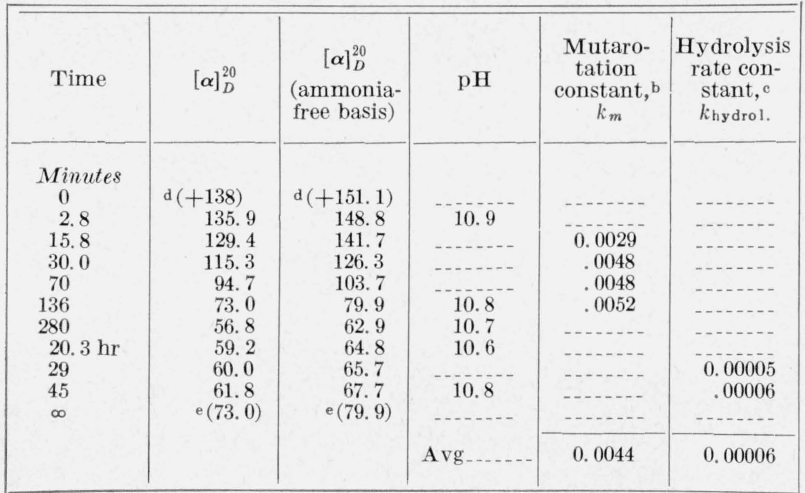

s Experiment 1, see table 4.

b $k_{m}=1 / t \log \left(r_{0}-r_{\infty}\right) /\left(r_{t}-r_{\infty}\right)$.

- k ky drol. $=1 /\left(t_{g}-t_{1}\right) \log \left(r_{1}-r_{\infty}\right) /\left(r_{2}-r_{\infty}\right)$.

d Calculated initial rotation.

e Calculated rotation for complete hydrolysis.

two substances exhibit within experimental error the same optical rotation $\left(+63.0^{\circ}\right)$. This value is presumably that of the alpha-beta equilibrium mixture, since in acid solution equilibrium is established quickly. The subsequent rise in optical rotation is attributed to slight hydrolysis. The mutarotation of
TABLE 2. Changes in optical rotation of $\alpha$-D-galactosylamine ammonia complex and of $\beta$-D-galactosylamine on dissolution in water and in $2.5 \mathrm{~N} \mathrm{HCl}$

\begin{tabular}{|c|c|c|c|}
\hline \multicolumn{2}{|c|}{ Alpha modification } & \multicolumn{2}{|c|}{ Beta modification } \\
\hline Time & {$[\alpha]_{D}^{20^{\mathrm{a}}}$} & Time & {$[\alpha]_{D}^{20}$} \\
\hline \multicolumn{2}{|c|}{$\begin{array}{c}\text { Experiment 2 } \\
\text { solution in } 2.5 \mathrm{~N} \mathrm{HCl}\end{array}$} & \multicolumn{2}{|c|}{$\begin{array}{c}\text { Experiment } 3 \\
\text { solutio. in } 2.5 \mathrm{~N} \mathrm{HCl}\end{array}$} \\
\hline $\begin{array}{l}\text { Min. } \\
3.0 \\
10.3 \\
225 \\
360 \\
22 \text { hr }\end{array}$ & $\begin{array}{r}+63.0 \\
63.3 \\
63.5 \\
63.9 \\
64.3\end{array}$ & $\begin{array}{c}3 \\
60 \\
90 \\
215 \\
72 \mathrm{hr}\end{array}$ & $\begin{array}{r}+63.1 \\
63.2 \\
64.3 \\
64.6 \\
66.6\end{array}$ \\
\hline \multicolumn{2}{|c|}{$\begin{array}{c}\text { Experiment } 1 \\
\text { solution in water } \mathrm{pH} 10.9\end{array}$} & \multicolumn{2}{|c|}{$\begin{array}{c}\text { Experiment } 4 \\
\text { solution in water }+\mathrm{NH}_{3} \mathrm{~b} \\
\mathrm{pH} 10.9\end{array}$} \\
\hline \multirow[t]{3}{*}{$\begin{array}{c}2.8 \\
15.8 \\
30 \\
136 \\
280 \\
20.3 \mathrm{hr}\end{array}$} & \multirow[t]{3}{*}{$\begin{array}{r}+148.8 \\
141.7 \\
126.3 \\
79.9 \\
62.9 \\
64.8\end{array}$} & $\begin{array}{c}3.1 \\
30 \\
60 \\
180 \\
24 \mathrm{hr}\end{array}$ & $\begin{array}{r}+62.7 \\
62.7 \\
62.7 \\
62.5 \\
62.4\end{array}$ \\
\hline & & \multicolumn{2}{|c|}{$\begin{array}{c}\text { Experiment } 5 \\
\text { solution in water } \mathrm{pH} 9.2\end{array}$} \\
\hline & & $\begin{array}{r}2.1 \\
5.1 \\
10.5 \\
21.1 \\
60 \\
120\end{array}$ & $\begin{array}{r}+62.2 \\
61.9 \\
61.2 \\
60.8 \\
60.5 \\
60.4\end{array}$ \\
\hline
\end{tabular}

a Ammonia-free basis.

b The solution of $\alpha$-D-galactosylamine ammonia complex in water had a $\mathrm{pH}$ of 10.9. For comparison, measurements of the rotation of $\boldsymbol{\beta}$-D-galactosylamine also were made in the presence of $\mathrm{NH}_{3}$ at this $\mathrm{pH}$.

the beta isomer in water and in water containing ammonia appears anomalous, in that the change in optical rotation, although small, is in the same direction as that of the alpha isomer. It is believed that this change is not due to the establishment of the alpha-beta equilibrium, but rather to a side reaction, the formation of a less dextrorotatory substance, presumably the digalactosylamine having a specific rotation of $+22^{\circ}[3]$.

As shown by the experiment given in table 3 , the side reaction causing the optical rotation to fall below the equilibrium value is enhanced by the presence of general acid catalysts, in this case the ammonium ion. A similar reaction was observed concurrently with the mutorotation of L-arabinosylamine [1]. We believe that the reaction involves the condensation of the amine with the imonium cation essentially as represented below:

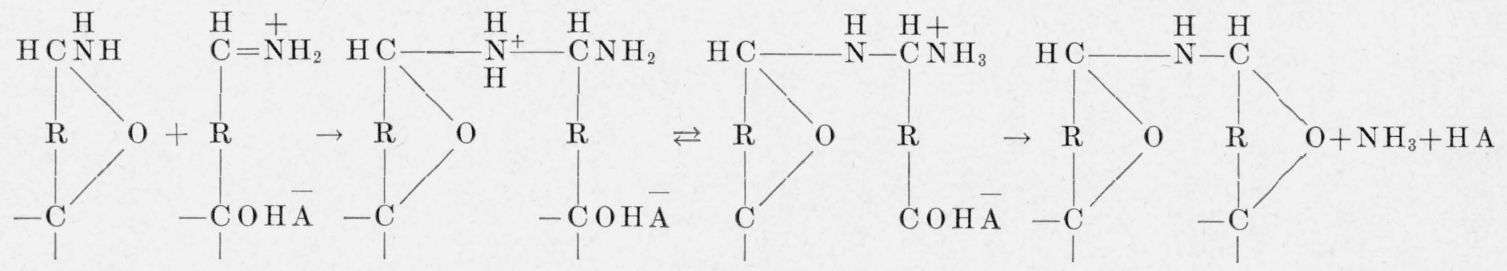


This mechanism requires the presence of both the free amine and the imonium cation. Relatively high concentrations of both constituents exist in alkaline solution in the presence of general acid catalysts, and hence the side reaction is of importance under these conditions. As pointed out in [1], the mechanism also accounts for the variation in the amount of the side reaction with the manner of mixing the glycosylamine and acid. Slow addition of the acid permits the amine present in excess to react with the imonium cation as it is formed.

TABLE 3. Change in optical rotation of $\beta$-D-galactosylamine in the presence of $1 \mathrm{~N} \mathrm{NH}_{4} \mathrm{Cl}+\mathrm{NH}_{3}$ at $p H 10.9$ a

\begin{tabular}{|c|c|}
\hline Time & {$[\alpha]_{D}^{20}$} \\
\hline & \\
\hline $\min$ & \\
2.4 & $+58.2^{\circ}$ \\
10.7 & 57.5 \\
60 & 55.8 \\
120 & 5.3 \\
300 & 54.5 \\
460 & 54.9 \\
\hline
\end{tabular}

a Experiment 6.

\section{Acid-Base Catalysis in the Mutarotation of $\alpha$-D-Galactosylamine}

Solutions of $\alpha$-D-galactosylamine ammonia complex in water react alkaline and contain free ammonia. A 0.1 -molar solution has a $\mathrm{pH}$ of about 10.9. To study the variation in the rate of mutarotation with $\mathrm{pH}$, measurements were made in solutions containing either additional base or an acid. The data are presented in table 4 and figure 1 . In figure 1 , curve 1 shows the mutarotation of the substance in water free from carbon dioxide, and curves 2 and 3 show the effect of increasing the alkalinity by the use of ammonia and sodium hydroxide, re-

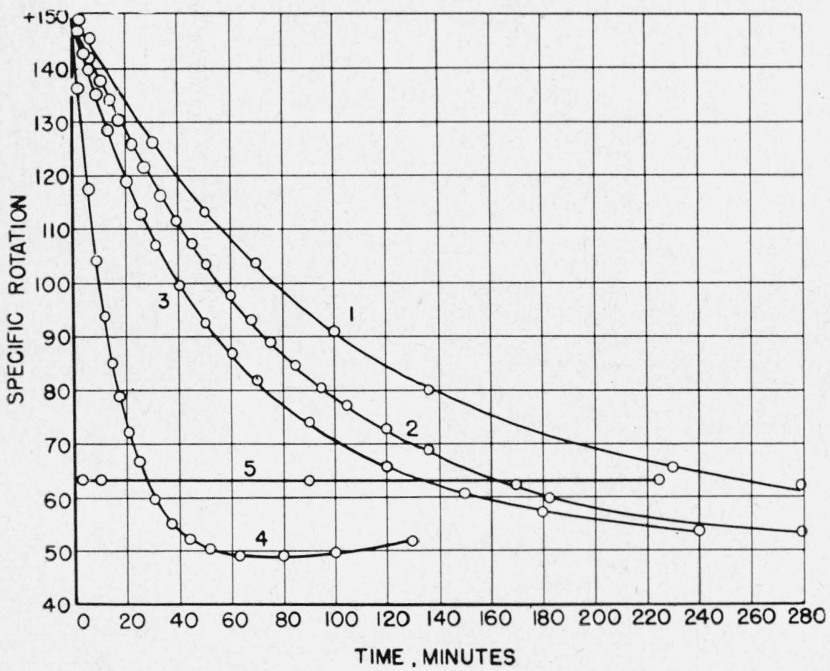

FiguRE 1. Mutarotation of $\alpha$-D-galactosylamine ammonia complex.

1. In water, $\mathrm{pH} 10.9$ (experiment 1 ); 2 . in water $+\mathrm{NH}_{3}, \mathrm{pH} 11.5$ (experiment 8 ); 3 . in $0.01 \mathrm{~N} \mathrm{NaOH}$ (experiment 7); 4 . in $0.5 \mathrm{~N} \mathrm{NH}_{4} \mathrm{Cl}+\mathrm{NH}_{3}, \mathrm{pH} 10.9$ (experiment 9 ); 5 , in $2.5 \mathrm{~N} \mathrm{HCl}$ (experiment 2). spectively. Curve 4 shows the effect of a substantial quantity of ammonium chloride and curve 5 of strong acid. In the presence of strong acid the optical rotation drops to the equilibrium value before the first measurement can be made. In the $\mathrm{pH}$ range 8.7 to 11.5 , solutions buffered with ammonium chloride and ammonia gave satisfactory rate constants (table 4 ). In some cases the muta-

\section{TABLE 4. Mutarotation of $\alpha$-D-galactosylamine}

[0.5 g $\alpha$-D-galactopyranosylamine ammonia complex dissolved in sufficient acid base or buffer to give a volume of $25 \mathrm{ml}$ at $20^{\circ} \mathrm{C}$, and the solvent composition listed opposite the experiment number. $\mathrm{pH}$ given is that of solution]

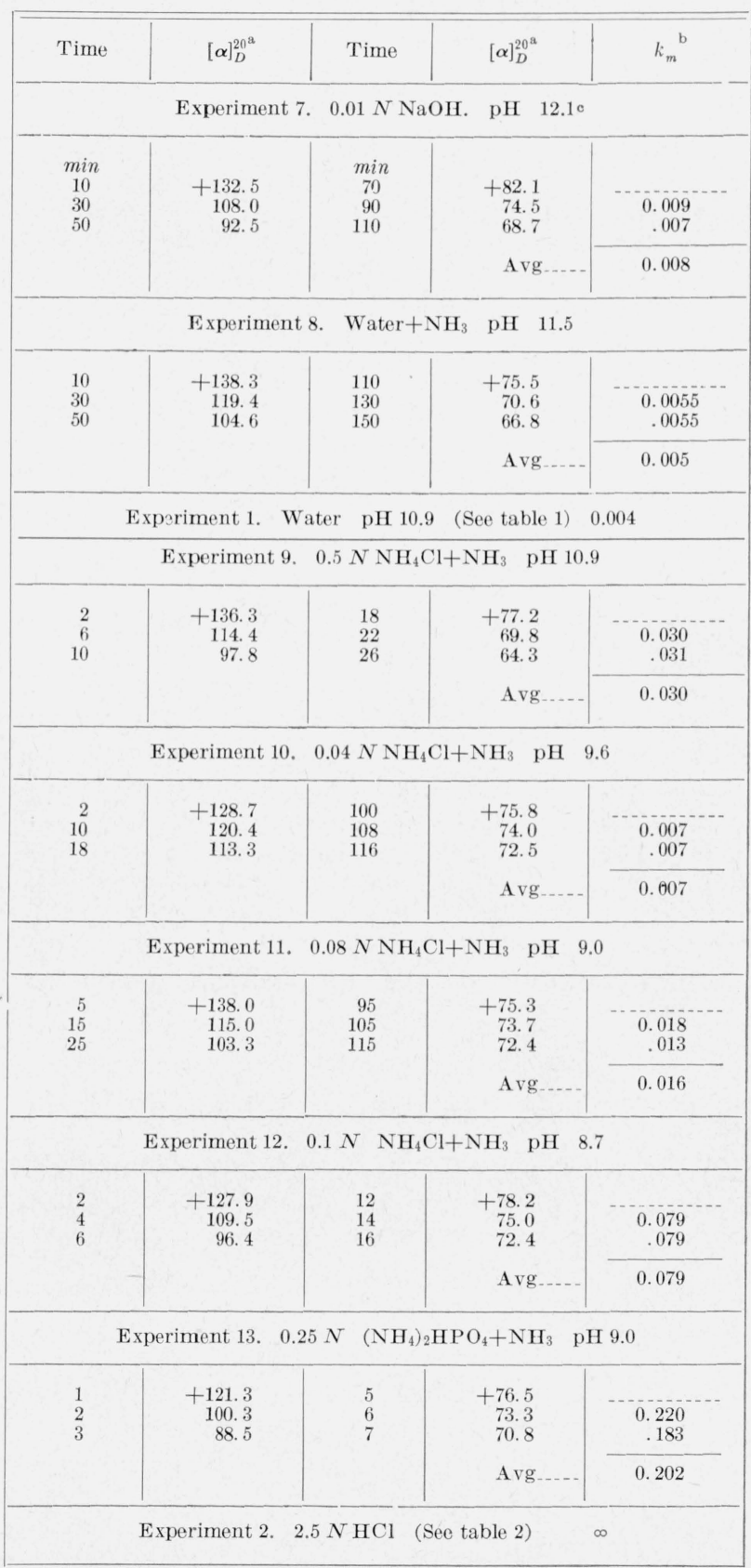

a Specific rotations expressed on ammonia-free basis.

b Determined by the method of Brönsted and Guggenheim [4]. c Approximate $\mathrm{pH}$. 
rotation appears to be caused not only by the establishment of the alpha-beta equilibrium, but also to some extent by the side reation discussed in the preceding paragraph.

The side reaction accounts for the drop in rotation below the equilibrium value of $+63^{\circ}$ (strikingly shown in curve 4 of fig. 1). It seems to be favored by the presence of general acid catalysts, particularly in alkaline solution. Presumably both the mutarotation and the slide reaction involve the intermediate formation of the imonium cation, and since separate treatment of the reactions does not seem feasible, no attempt was made to determine separate rate constants; rather, a rate constant $k_{m}$ was calculated for the over-all process.

TABLE 5. Mutarotation constants for $\alpha$-D-galactosylamine ammonia complex

\begin{tabular}{|c|c|c|c|c|c|c|}
\hline $\begin{array}{l}\text { Experi- } \\
\text { ment }\end{array}$ & $\mathrm{pH}$ & {$\left[\mathrm{H}^{+}\right]$} & {$\left[\mathrm{OH}^{-}\right]$} & {$\left[\mathrm{NH}_{4}^{+}\right]$} & $k_{\mathrm{m}}$ & $\begin{array}{l}k_{\mathrm{m}}(\mathrm{cor}-\mathrm{r}-\mathrm{a} \\
\text { rected }{ }^{a}\end{array}$ \\
\hline $\begin{array}{r}7 \\
8 \\
1 \\
9 \\
10 \\
11 \\
12 \\
13 \\
2\end{array}$ & $\begin{array}{c}12.0 \\
11.5 \\
10.9 \\
10.9 \\
9.6 \\
9.0 \\
8.7 \\
9.0 \\
2.5 \mathrm{NHCl}\end{array}$ & $\begin{array}{r}10^{-12} \\
\text { 3. } 2 \times 10^{-12} \\
\text { 1. } 3 \times 10^{-11} \\
\text { 1. } 3 \times 10^{-11} \\
\text { 2. } 5 \times 10^{-11} \\
\text { 1. } 0 \times 10^{-9} \\
\text { 4. } 8 \times 10^{-9} \\
1.0 \times 10^{-9}\end{array}$ & $\begin{array}{r}10^{-2} \\
\text { 3. } 2 \times 10^{-3} \\
\text { 7. } 9 \times 10^{-4} \\
\text { 7. } 9 \times 10^{-4} \\
\text { 4. } 0 \times 10^{-5} \\
\text { 1. } 0 \times 10^{-5} \\
\text { 8. } 5 \times 10^{-6} \\
\text { 1. } 0 \times 10^{-5}\end{array}$ & $\begin{array}{c}0.5 \\
.04 \\
.08 \\
1.0 \\
0.5\end{array}$ & $\begin{array}{l}0.008 \\
.005 \\
.004 \\
.030 \\
.007 \\
.016 \\
.079 \\
.202 \\
0 \infty\end{array}$ & $\begin{array}{r}0.008 \\
.005 \\
.004 \\
.004 \\
.005 \\
.012 \\
.027 \\
\text { b. } 176\end{array}$ \\
\hline
\end{tabular}

a Corrected for the catalytic effect of ammonium ion.

b Higher constant due to catalytic effect of the phosphate used as a buffer.

c Too rapid to measure.

To evaluate the effect of acid and base catalysts on the mutarotation, the rate constants reported in tables 4 and 5 were determined by the method of Brönsted and Guggenheim [4]. This method was used because it does not require the final, or equilibrium rotation. A comparison of the data of experiments 1 and 9 and of 11 and 13 show that the process is catalyzed by ammonium ion, and by acid phosphate, respectively. Thus the reactions clearly show general acid catalysis. If, for simplicity, the system is restricted to solutions containing water and ammonium salts of strong acids, the rate constant is given by the following expression:

$$
k_{m}=k_{\mathrm{H}_{2} \mathrm{O}}+k_{\mathrm{H}}\left[\mathrm{H}^{+}\right]+k_{\mathrm{OH}}\left[\mathrm{OH}^{-}\right]+k_{\mathrm{NH}_{4}}\left[\mathrm{NH}_{4}^{+}\right] .
$$

From equations representing the rate constants for experiments 1 and $9, k_{\mathrm{NH}_{4}}$ was found to be 0.052 . $\mathrm{By}$ use of this value, $k_{m}$ was corrected for the cataly tic effect of the ammonium ion. The corrected values are given in the right-hand column of table 5 and are plotted in figure 2. It will be seen from the figure that in acid solution the mutarotation is too rapid to measure; with reduction in the oxonium ion concentration the rate decreases to a minimum and then increases. With the assumption that in highly alkaline solution the catalytic effect due to oxonium ion becomes small and may be neglected, the rate constants of experiments 1 and 7 give values of 0.004 and 0.4 , respectively, for $k_{\mathrm{H}_{2} \mathrm{O}}$ and $k_{\mathrm{OH}}$. Use of these values in equations representing the data from experiments 11 and 12 , and solution of the equations, gives for $k_{\mathrm{H}}$ an average value of $6 \times 10^{5}$.

Thus, in the absence of ammonium ion,

$$
k_{m}=0.004+6 \times 10^{6}\left[\mathrm{H}^{+}\right]+0.4\left[\mathrm{OH}^{-}\right] .
$$

The dotted curve of figure 2 corresponds to this equation.

It was suggested in [1] that the mutarotations of both the sugars and the glycosylamines take place by several mechanisms. The mechanism of eq 1 was shown to be promoted by acids in general and to be of importance for the mutarotation of both the sugars and the glycosylamines. It was pointed out that a base-catalyzed mechanism such as that of eq 2 is of first importance for the mutarotation of the sugars, but that base catalysis could not be demonstrated in the case of L-arabinosylamine. However, the data of table 5 and figure 2 show that the mutarotation constants of $\alpha-\mathrm{D}$-galactosylamine ammonia complex rise in highly alkaline solution, and hence the over-all change due to the mutarotation and the side reaction is catalyzed not only by acids, but also by hydroxyl ion.

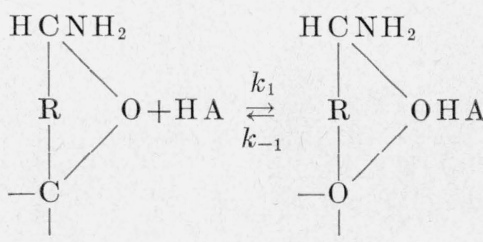<smiles>CC(C)(O)C=[Ni]</smiles><smiles>[R]C(N)C(C)(C)O</smiles><smiles></smiles>

all open-chain forms
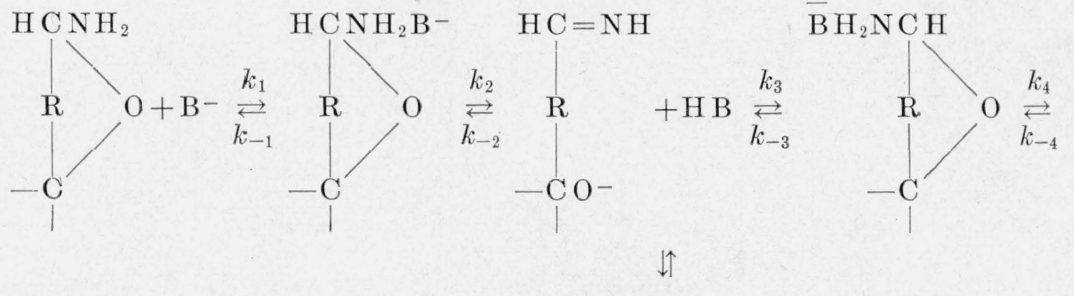

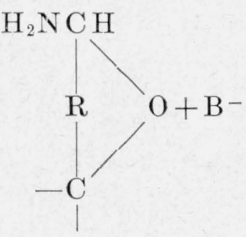

all open-chain forms 


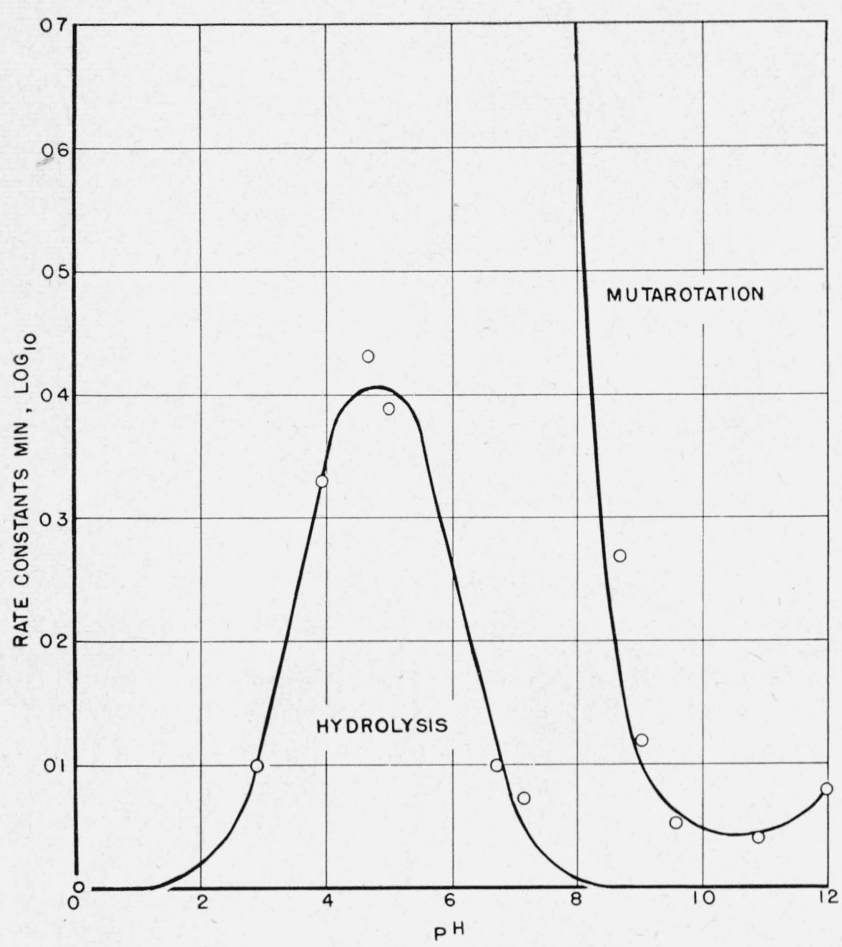

FIgURE 2. Rate constants for the mutarotation and hydrolysis of $\alpha$-D-galactosylamine.

\section{Hydrolysis Reaction}

To study the hydrolysis of D-galactosylamine, measurements of optical rotation were made largely in the $\mathrm{pH}$ range in which equilibrium of the anomeric forms of the amine is established rapidly. Under these conditions, the change in optical rotation can be ascribed exclusively to the hydrolysis reaction, and the rate constant can be obtained by application of the conventional first-order formula:

$$
k_{\text {hydrol }}=\frac{1}{t_{2}-t_{1}} \log \frac{r_{t_{1}}-r_{\infty}}{r_{t_{2}}-r_{\infty}},
$$

where $r_{t_{1}}$ and $r_{t_{2}}$ are the rotations at times $t_{1}$ and $t_{2}$, respectively, and $r_{\infty}$ is the specific rotation of the fully hydrolyzed material. The hydrolysis rate constants obtained at various $\mathrm{pH}$ levels are given in table 6 and figure 2 .

We have shown previously from theoretical considerations [1] that the effect of the oxonium and hydroxyl ion concentrations on the hydrolysis constant should conform to an equation of the type:

$$
k_{\text {hydrol }}=\frac{1}{\mathrm{~K}_{1}+\mathrm{K}_{2}\left[\mathrm{H}^{+}\right]+\mathrm{K}_{3}\left[\mathrm{OH}^{-}\right]} .
$$

When the data of experiments 15, 18, and 19 were applied to this equation, $\mathrm{K}_{1}, \mathrm{~K}_{2}$, and $\mathrm{K}_{3}$ were found to be $22.5,6.16 \times 10^{4}$ and $1.55 \times 10^{9}$, respectively. Thus,

$$
k_{\mathrm{hydrol}}=\frac{1}{22.5+6.16 \times 10^{4}\left[\mathrm{H}^{+}\right]+1.55 \times 10^{9}\left[\mathrm{OH}^{-}\right]} .
$$

The solid curve of figure 2 represents a plot of this expression; the circles represent the experimentally determined rate constants given in table 6 . The calculated maximum rate is at $\mathrm{pH} 4.8$.

The data of experiment 16 of table 6 show an effect that requires explanation. The optical rotation of the material on hydrolysis increases to a value higher than the equilibrium value corresponding to the

\section{TABLE 6. Hydrolysis of $\alpha$-D-galactosylamine}

[0.5 g $\alpha$-D-galactosylamine lammonia complex dissolved in sufficient acid, base or

\begin{tabular}{|c|c|c|c|}
\hline Time & {$[\alpha]_{D}^{20^{\mathrm{a}}}$} & $\mathrm{pH}$ & $k_{\text {bydrol }}$ \\
\hline \multicolumn{2}{|c|}{$\begin{array}{l}\text { Experiment } 1 \\
\text { Ste table } 1\end{array}$} & $\begin{array}{l}\text { Water } \\
10.9\end{array}$ & 0.00006 \\
\hline \multicolumn{4}{|c|}{$\begin{array}{l}\text { Experiment } 14.5 \text { volumes of } M \mathrm{KH}_{2} \mathrm{PO}_{4}+ \\
2 \text { volumes } N \mathrm{NaOH} \text { diluted to } 10 \text { volumes }\end{array}$} \\
\hline \multirow[t]{2}{*}{$\begin{array}{c}\min \\
15.3 \\
75 \\
150 \\
26 \mathrm{hr}\end{array}$} & \multirow[t]{2}{*}{$\begin{array}{r}+62.9 \\
72.3 \\
76.9 \\
78.5\end{array}$} & 7.1 & $\begin{array}{r}0.007 \\
.007 \\
\end{array}$ \\
\hline & & Avg.. & 0.007 \\
\hline \multicolumn{4}{|c|}{$\begin{array}{l}\text { Experiment } 15.5 \text { volumes of } M \mathrm{KH}_{2} \mathrm{PO}_{4}+ \\
1 \text { volume } N \mathrm{NaOH} \text { diluted to } 10 \text { volumes }\end{array}$} \\
\hline \multirow[t]{2}{*}{$\begin{array}{l}10.8 \\
26.6 \\
60.1 \\
20 \mathrm{hr}\end{array}$} & \multirow[t]{2}{*}{$\begin{array}{r}+64.6 \\
69.3 \\
75.8 \\
80.2\end{array}$} & 6.7 & $\begin{array}{r}0.010 \\
.011 \\
\end{array}$ \\
\hline & & Avg & 0.010 \\
\hline \multicolumn{4}{|c|}{$\begin{array}{l}\text { Experiment } 16.5 \text { volumes } N \text { acetic acid }+ \\
2 \text { volumes } N \text { NaOH diluted to } 10 \text { volumes }\end{array}$} \\
\hline \multirow[t]{2}{*}{$\begin{array}{r}2.2 \\
3.4 \\
6.0 \\
9.8 \\
12.8 \\
32.7 \\
71 \\
90 \\
150\end{array}$} & \multirow[t]{2}{*}{$\begin{array}{r}+58.5 \\
60.4 \\
64.8 \\
70.7 \\
74.1 \\
82.0 \\
81.1 \\
80.5 \\
79.7\end{array}$} & 5.0 & $\begin{array}{r}0.031 \\
.036 \\
.042 \\
.045 \\
\hdashline \\
\hdashline\end{array}$ \\
\hline & & A $v g$ & 0.039 \\
\hline \multicolumn{4}{|c|}{$\begin{array}{l}\text { Experiment } 17 \text {. } 5 \text { volumes of } N \text { acetic acid } \\
+1 \text { volume } N \text { NaOH diluted to } 10 \text { volumes }\end{array}$} \\
\hline $\begin{array}{r}1.7 \\
7.5 \\
10.3 \\
18.6 \\
32.3 \\
60 \\
290\end{array}$ & $\begin{array}{r}+54.9 \\
63.7 \\
67.6 \\
74.3 \\
77.4 \\
76.0 \\
\text { ь } 74.6\end{array}$ & 4. 7 & $\begin{array}{r}0.037 \\
.042 \\
.051 \\
0.043\end{array}$ \\
\hline \multicolumn{4}{|c|}{ Experiment $18 . \quad 1 N$ acetic acid } \\
\hline \multirow[t]{2}{*}{$\begin{array}{c}2.4 \\
10.1 \\
15.1 \\
30.0 \\
60 \\
390 \\
25 \mathrm{hr}\end{array}$} & \multirow[t]{2}{*}{$\begin{array}{r}+57.5 \\
65.4 \\
68.5 \\
73.9 \\
75.8 \\
75.2 \\
74.6\end{array}$} & 3.9 & $\begin{array}{r}0.032 \\
.031 \\
.036 \\
\end{array}$ \\
\hline & & Avg-- & 0.033 \\
\hline
\end{tabular}
buffer to give a volume of $25 \mathrm{ml}$ at $20^{\circ} \mathrm{C}$. Solvents are listed with experiment numbers] 
TABLE 6.-Hydrolysis of $\alpha$-D-galactosylamine-Continued

$0.5 \mathrm{~g} \alpha$-D-galactosylamine ammonia complex dissolved in sufficent acid, base or buffer to give a volume of $25 \mathrm{ml}$ at $20^{\circ} \mathrm{C}$. Solvents are listed with experiment numbers]

\begin{tabular}{|c|c|c|c|}
\hline Time & {$[\alpha]_{D}^{20^{a}}$} & $\mathrm{pH}$ & $k_{\text {hydrol }}$ \\
\hline \multicolumn{4}{|c|}{ Experiment $19.5 \mathrm{~N}$ acetic acid } \\
\hline \multirow[t]{2}{*}{$\begin{array}{l}2.4 \\
16.3 \\
30.7 \\
60 \\
23 \mathrm{hr}\end{array}$} & $\begin{array}{r}+62.4 \\
67.3 \\
69.8 \\
74.4 \\
79.3\end{array}$ & 2.9 & $\begin{array}{r}0.011 \\
.009 \\
.009 \\
\end{array}$ \\
\hline & & Avg_- & 0.010 \\
\hline
\end{tabular}

Experiment 2. $2.5 \mathrm{~N} \mathrm{HCl}$

\begin{tabular}{|c|c|c|c|}
\hline \multirow[t]{2}{*}{$\begin{array}{c}3.0 \\
225 \\
22 \mathrm{hr} \\
\infty\end{array}$} & \multirow[t]{2}{*}{$\begin{array}{r}+63.0 \\
63.5 \\
64.3 \\
\text { с } 79.9\end{array}$} & - & $\begin{array}{r}0.00006 \\
.00003 \\
\end{array}$ \\
\hline & & Avg. - & 0.00004 \\
\hline
\end{tabular}

a Expressed on the ammonia-free basis.

b Constant.

- Calculated rotation for complete hydrolysis.

TABLE 7. Mutarotation of hydrolysis product a before and after the addition of $\alpha$-D-galactose ${ }^{\mathrm{b}}$

\begin{tabular}{|c|c|c|}
\hline Time & $\begin{array}{l}\text { Observed } \\
\text { rotation, } \\
{ }_{S}^{S}\end{array}$ & $k_{m}$ \\
\hline $\begin{array}{c}\min \\
32.7 \\
71 \\
90 \\
150\end{array}$ & $\begin{array}{r}+17.31 \\
17.12 \\
16.98 \\
\text { d } 16.93\end{array}$ & $\begin{array}{r}0.008 \\
.015 \\
\end{array}$ \\
\hline $\begin{array}{l}\text { е } 200 \\
202.8 \\
207.2 \\
215.2 \\
240.3 \\
260\end{array}$ & $\begin{array}{r}+18.22 \\
18.13 \\
18.00 \\
17.80 \\
\text { d } 17.72\end{array}$ & $\begin{array}{l}0.020 \\
.020 \\
.021\end{array}$ \\
\hline
\end{tabular}

a Experiment 16, table 6.

b $0.5 \mathrm{~g}$ of $\alpha$-D-galactosy!amine ammonia complex in $25 \mathrm{ml}$ of solution. After equilibrium was reached, $0.0170 \mathrm{~g}$ of $\alpha$-D-galactose was added to $20 \mathrm{ml}$ of the solution, and the resulting mutarotation was observed in a 4-dm tube

- As hydrolysis is not entirely complete, the mutarotation constant would be expected to be low and to increase with time.

d Constant.

$\alpha$-D-Galactose added to solution.

sugar presumably formed, and then slowly decreases. A similar drop in rotation was observed in experiments 17 and 18 . The phenomenon was studied further by the addition of $\alpha$-D-galactose to the solution of experiment 16 after hydrolysis had taken place. It will be seen from table 7 that the slow decrease in optical rotation observed in experiment 16 is comparable to that caused by the mutarotation of $\alpha$-D-galactose in the same solution. The effect is detected only when conditions are such that the rate of hydrolysis is high and the rate of mutarotation of the free sugar is low. Thus it appears that under these conditions the proportion of the alpha pyranose modification of the sugar temporarily exceeds the equilibrium proportion, and that restoration of the equilibrium is accompanied by a decrease in optical rotation. A simple explanation for the effect is that the rate constants for the system

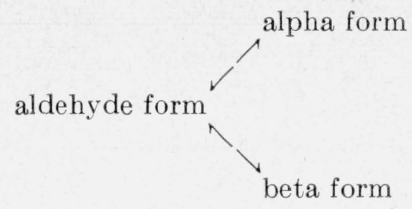

are such that the equilibrium between the aldehyde and the alpha modification is attained more quickly than that between the aldehyde and the beta modification. Thus, the proportion of the alpha form increases until equilibrium is established with the aldehyde, after which the beta form continues to increase at the expense of the alpha until finally all modifications are in equilibirium.

\section{Periodate Oxidation of the $N$-Acetyl-D- Galactosylamines}

On periodate oxidation, essentially as employed by Niemann and Hays [5] in the study of $N$-acetyl-Dglucosylamine, the specific rotation of $N$-acetyl- $\alpha$-Dgalactosylamine decreased rapidly from the initial value of $+194.9^{\circ}$ to about $+60^{\circ}$ and then decreased slowly, whereas the specific rotation of $N$-acetyl- $\beta$-Dgalactosylamine changed rapidly from $+9.8^{\circ}$ to about $-96^{\circ}$. In each case 2 moles of periodate were consumed rapidly. Both of the oxidation products, after bromine oxidation and hydrolysis, vielded glyceric acid, identified colorimetrically [6]. The consumption of 2 moles of periodate and the identification of a three-carbon fragment after subsequent oxidation and hydrolysis, show that both compounds are pyranoses and hence they must constitute an alpha-beta pyranose pair. Presumably the products having rotations ${ }^{2}$ of $+60^{\circ}$ and $-96^{\circ}$ are, respectively, $\mathrm{D}^{\prime}$-acetamido-D-hydroxymethyldiglycolic aldehyde IV and $\mathrm{L}^{\prime}$-acetamido-D-hydroxymethyldiglycolic aldehyde $\mathrm{V}$. The alpha and beta modifications of all $N$-acetyl-D-aldohexopyranosylamines will give one or the other of these dialdehydes, and the corresponding enantiomorphs will give products whose rotations differ from these merely in direction. Hence the optical rotations of $\pm 60^{\circ}$ and $\pm 96^{\circ}$ for the products of periodate oxidation can be used for the assignment of ring structure, as well as alpha or beta configuration for any $N$-acetyl-aldohexosylamine.

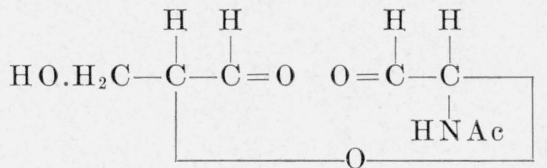

D'-Acetamido-D-hydroxymethyl-diglycolic aldehyde.

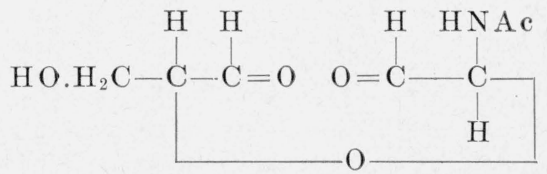

L'-Acetamido-D-hydroxymethyl-diglycolic aldehyde.

2 The values $+60^{\circ}$ and $-96^{\circ}$ are based on the weight of the original compounds These correspond to specific rotations of $+70^{\circ}$ and $-112^{\circ}$, respectively, based on the corresponding weights of the resultant dialdehydes. 


\section{Experimental Details}

\section{1. $\alpha$-D-Galactopyranosylamine Ammonia Complex}

Forty grams of D-galactose and $1 \mathrm{~g}$ of ammonium chloride were suspended in $100 \mathrm{ml}$ of anhydrous methanol, and ammonia was passed into the mixture until dissolution of the material was complete. The solution was stored at room temperature for several days, and finally in the refrigerator for 1 day. The product that crystallized from solution was separated, washed with methanol and dried for 2 hours over sodium hydroxide at reduced pressure. The crude yield was about $35 \mathrm{~g}$, having a specific rotation of $+87^{\circ}$. This value is in accord with that reported in [2]. The product was recrystallized by dissolving it in 10 parts of cold 3 -percent aqueous ammonia and adding 10 parts of methanol saturated with ammonia at $0^{\circ} \mathrm{C}$. The crystals, which formed in the course of a few minutes, were collected on a filter and washed with methanol saturated with ammonia. They were then stored in an atmosphere of ammonia in a desiccator containing sodium hydroxide. Prior to analysis or use, the excess ammonia was removed from the material by evacuation of the desiccator for 15 minutes. On repeated recrystallization $[\alpha]_{D}^{20}$ rose from $+87^{\circ}$ to $+138^{\circ}$ initially (water, $c=5$ ). Further recrystallization failed to change this value. The product contained approximately 1 mole of ammonia per mole of amine but the composition varied slightly in different preparations, apparently because of the tendency of the ammonia to escape.

Analysis: Calculated for $\mathrm{C}_{6} \mathrm{H}_{16} \mathrm{O}_{5} \mathrm{~N}_{2}$ : C, 36.7; H, $8.2 ; \mathrm{N}, 14.2$. Found: C, $36.5 ; \mathrm{H}, 8.4 ; \mathrm{N}, 12.9$.

\section{2. $\beta$-D-Galactopyranosylamine}

Storage of $\alpha$-D-galactosylamine ammonia complex over phosphoric anhydride for several months gave an amorphous residue with a specific rotation of $+63^{\circ}$. On dissolution of this material in water, followed by the addition of ethanol to incipient turbidity, a crystalline product formed that appeared to be the same as that of de Bruyn and Van Leent [2]. The material was obtained more readily by dissolving the crude ammonia complex in two parts of warm water, and after half an hour, filtering and adding four parts of methanol and two parts of isopropanol. The large rectangular prisms that separated were washed with methanol and dried over sodium hydroxide. After two crystallizations the compound gave the following analysis: Calculated for $\mathrm{C}_{6} \mathrm{H}_{13} \mathrm{O}_{5} \mathrm{~N}$ : $\mathrm{C}, 40.2 ; \mathrm{H}, 7.3 ; \mathrm{N}, 7.8$. Found: C, $40.1 ; \mathrm{H}, 7.4 ; \mathrm{N}, 7.8 .[\alpha]_{D}^{20}=+62.2^{\circ}(2.1 \mathrm{~min}$, water, $c=2$ ).

\subsection{Pentaacetyl- $\alpha$-D-Galactopyranosylamine}

Ten grams of finely powdered $\alpha$-D-galactosylamine ammonia complex was added to a previously cooled mixture of $100 \mathrm{ml}$ of pyridine and $50 \mathrm{ml}$ of acetic anhydride in a flask equipped with a mechanical stirrer and immersed in a mixture of ice and salt.
Stirring was continued for 3 days in the ice-salt bath and for 1 day at room temperature. The reaction mixture was diluted with several volumes of petroleum ether, which precipitated a sirup. The liquid was decanted and the sirup brought to crystallization by the addition of isoamyl alcohol. The crystals weighed $3.5 \mathrm{~g}$ and had a specific rotation of $+112^{\circ}$. After several recrystallizations from 95percent ethanol, the product, pentaacetyl- $\alpha$-D-galactopyranosylamine, melted at $172^{\circ}$ to $173^{\circ} \mathrm{C}$; $[\alpha]_{D}^{20}=$ $+117.4^{\circ}\left(\mathrm{CHCl}_{3}, c=2\right)$.

Analysis: Calculated for $\mathrm{C}_{16} \mathrm{H}_{23} \mathrm{O}_{10} \mathrm{~N}$ : C, $49.35 ; \mathrm{H}$. 5.95 ; N, 3.60 ; found: C, $49.6 ; \mathrm{H}, 6.0 ; \mathrm{N}, 3.6$.

\subsection{Pentaacetyl- $\beta$-D-Galactopyranosylamine}

Ten grams of ammonia-free galactosylamine of specific rotation $+62^{\circ}$ was treated with a mixture of pyridine and acetic anhydride as described for the acetylation of the alpha isomer. The amine dissolved in the acetylation mixture in the course of several hours, and the solution was then poured into ice and water. The crystals that formed were separated by filtration, and the aqueous filtrate was extracted with chloroform to recover additional material. The combined yield of crude pentaacetylgalactosylamine was $18 \mathrm{~g}$, having a specific rotation of $+35^{\circ}$. After recrystallization from chloroform with the addition of petroleum ether, and two recrystallizations from ethanol, the product, pure pentaacetyl- $\beta$-D-galactopyranosylamine, melted at $173^{\circ} \mathrm{C} . \quad[\alpha]_{D}^{20}=+34.7^{\circ}\left(\mathrm{CHCl}_{3}, \quad c=2\right)$. The constants were unchanged by further recrystallization.

Analysis: Calculated for $\mathrm{C}_{16} \mathrm{H}_{23} \mathrm{O}_{10} \mathrm{~N}$ : C, $49.35 ; \mathrm{H}$, 5.95 ; N, 3.60 ; found: C, $49.6 ; \mathrm{H}, 6.1 ; \mathrm{N}, 3.6$.

\subsection{N-Acetyl- $\alpha$-D-Galactopyranosylamine and N-Acetyl- $\beta$-D-Galactopyranosylamine}

Both the alpha and beta forms of pentaacetyl-Dgalactosylamine were deacetylated by the catalytic barium methylate method [7] in the following manner: Ten grams of the material was dissolved in $100 \mathrm{ml}$ of anhydrous methanol containing $10 \mathrm{ml}$ of $0.4 N$ barium methylate. The mixture was allowed to stand for $1 \mathrm{hr}$ and was then treated with an exactly equivalent amount of $0.4 \quad N$ sulfuric acid. Barium sulfate was removed by filtration of the mixture on a Büchner funnel heavily coated with diatomaceous earth and decolorizing carbon, and the residue was washed with water. The filtrate was concentrated under reduced pressure to a sirup from which the $N$-acetylgalactosylamine crystallized. The crystals were separated and washed with ethanol.

$N$-Acetyl- $\alpha$-D-galactopyranosylamine. The crystalline product, obtained from $10 \mathrm{~g}$ of pentaacetyl- $\alpha$ D-galactopyranosylamine by the process outlined above, weighed $5.5 \mathrm{~g}$ and had a specific rotation of $+193^{\circ}$. After two recrystallizations from warm methanol with the addition of isopropanol, pure $N$-acetyl- $\alpha$-D-galactopyranosylamine was obtained, $[\alpha]_{D}^{20}=+194.9^{\circ}$ (water, $c=2$ ); mp $179^{\circ}$ to $180^{\circ} \mathrm{C}$.

Analysis: Calculated for $\mathrm{C}_{8} \mathrm{H}_{15} \mathrm{O}_{6} \mathrm{~N}$ : C, 43.43; H, 6.84; N, 6.33. Found: C, 43.5; H, 6.8; N, 6.3. 
$N$-Acetyl- $\beta$-D-galactopyranosylamine. The product from $10 \mathrm{~g}$ of pentaacetyl- $\beta$-D-galactopyranosylamine $(5.5 \mathrm{~g})$ having a specific rotation of $+10^{\circ}$ was recrystallized twice from 20 parts of warm water by concentration in vacuum. The pure material, $N$ acetyl- $\beta$-D-galactopyranosylamine, melted at $233^{\circ} \mathrm{C}$; $[\alpha]_{D}^{20}=+9.8^{\circ}$ (water, $c=2$ ).

Analysis: Calculated for $\mathrm{C}_{8} \mathrm{H}_{15} \mathrm{O}_{6} \mathrm{~N}$ : C, 43.43; H, $6.84 ; \mathrm{N}, 6.33$. Found: C, 43.3; H, 6.9; N, 6.2.

\subsection{Periodate Oxidation of $N$-Acetyl- $\alpha$-D-Galacto- pyranosylamine and $N$-Acetyl- $\beta$-D-Galactopyran- osylamine.}

A 1-g sample of either $N$-acetyl- $\alpha$-D-galactopyranosylamine or $N$-acetyl- $\beta$-D-galactopyranosylamine was dissolved at $20^{\circ} \mathrm{C}$ in sufficient $0.29 \mathrm{M}$ sodium metaperiodate to give a volume of $50 \mathrm{ml}$, and the course of the oxidation was followed by the change in optical rotation. The results, given in table 8 and figure 3, show that in each case there was a rapid change followed by a slower change. At points near and after the termination of the rapid change, $10-\mathrm{ml}$ aliquots of the solution were pipetted into glass-stoppered flasks containing $20 \mathrm{ml}$ of $0.1 \mathrm{~N}$ sodium arsenite, $10 \mathrm{ml}$ of a saturated solution of $\mathrm{NaHCO}_{3}$, and $1 \mathrm{ml}$ of a 20 -percent solution of KI. After $15 \mathrm{~min}$. the excess arsenite was titrated with $0.1 N$ iodine. In both cases, substantially 2 moles of periodate per mole of $N$-acetylgalactosylamine had been used at the termination of the rapid change.

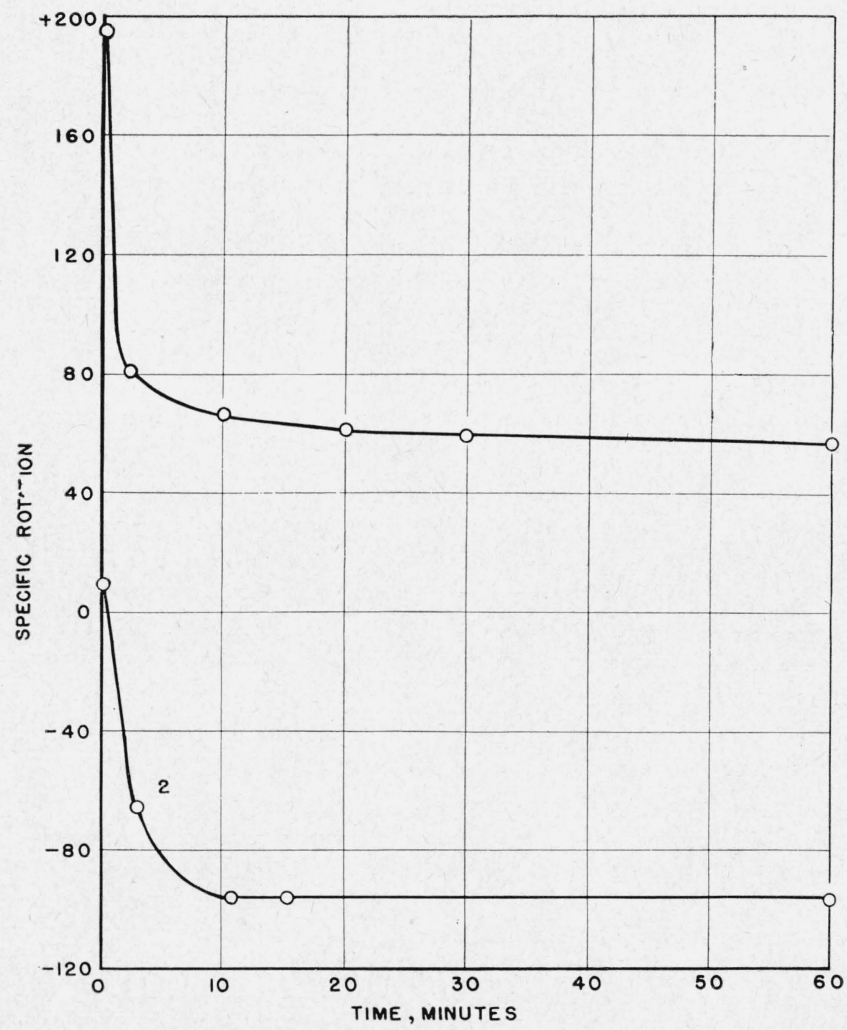

Figure 3. Periodate oxidation of $N$-acetyl-D-galactosylamines 1. $N$-A cetyl- $\alpha$-D-galactosylamine; $2 . N$-A cetyl- $\beta$-D-galactosylamine.
TABLE 8. Periodate oxidation of $N$-acetyl-D-galactosylamines ${ }^{\text {a }}$

\begin{tabular}{|c|c|c|c|}
\hline \multirow{2}{*}{$\begin{array}{c}\text { Reaction } \\
\text { time }\end{array}$} & \multicolumn{2}{|c|}{ Optical rotation } & \multirow{2}{*}{$\begin{array}{l}\text { Moles } \\
\text { periodate } \\
\text { per mole } \\
\text { amine }\end{array}$} \\
\hline & ${ }^{\circ} \mathrm{S}$ b & {$[\alpha]_{\mathrm{D}}^{20^{\circ}}$} & \\
\hline \multicolumn{4}{|c|}{$N$-acetyl- $\alpha$-D-galactosylamine } \\
\hline $\begin{array}{c}\min \\
0 \\
2.2 \\
10.1 \\
20.0 \\
30.0 \\
60.0\end{array}$ & $\begin{array}{r}(+22.52) \\
+9.46 \\
7.77 \\
7.07 \\
6.89 \\
6.59\end{array}$ & $\begin{array}{c}(+194.9) \\
+81.4 \\
+66.9 \\
+60.8 \\
+59.3 \\
+56.7\end{array}$ & $\begin{array}{l}-1 .-1 \\
1.04 \\
2.04\end{array}$ \\
\hline \multicolumn{4}{|c|}{$N$-acetyl- $\beta$-D-galactosylamine } \\
\hline $\begin{array}{c}0 \\
3.0 \\
10.7 \\
15.4 \\
60.0\end{array}$ & $\begin{array}{c}(+1.13) \\
-7.55 \\
-10.97 \\
-11.13 \\
-11.07\end{array}$ & $\begin{array}{l}(+9.8) \\
-65.1 \\
-94.5 \\
-95.9 \\
-95.4\end{array}$ & $\begin{array}{l}2.04 \\
2.04\end{array}$ \\
\hline
\end{tabular}

a $1 \mathrm{~g}$ of $\mathrm{N}$-acetylgalactosylamine in $50 \mathrm{ml}$ of $0.29 \mathrm{M}$ sodium metaperiodate. b Read in a 2-dm tube.

c Based on the weight of $N$-acetylgalactosylamine.

\subsection{Mutarotation and Hydrolysis Measurements}

The mutarotation and hydrolysis reactions were followed by measurement of the changes in optical rotation that occurred in solutions of the compounds in water containing known amounts of acids and bases essentially as described in [1]. In each experiment $0.5 \mathrm{~g}$ of crystalline amine was placed in a volumetric flask, and sufficient acid, base or buffer solution at $20^{\circ} \mathrm{C}$ was added to give a volume of $25 \mathrm{ml}$. Because of the ammonia present in $\alpha$-galactosylamine ammonia complex, its aqueous solution was highly alkaline. To obtain less alkaline solutions, the substance was dissolved in sufficient aqueous hydrochloric acid to give the quantities of $\mathrm{NH}_{4} \mathrm{Cl}$ reported in experiments 10,11 , and 12 . In experiments 6 and 9 , ammoniacal solutions of $\mathrm{NH}_{4} \mathrm{Cl}$ were added to the compounds. The rate constants are expressed in common logarithms and minutes.

\section{Summary}

A study of the reactions and properties of the products obtained by reaction of ammonia with galactose has revealed that one of the two previously known galactosylamines is a mixture. The crude material, by recrystallization from aqueous ammonia gave an isomer containing 1 mole of loosely bound ammonia, and having a specific rotation of $+138^{\circ}$, and the previously known galactosylamine of specific rotation $+62.2^{\circ}$. The two modifications of galactosylamine, on acetylation, gave crystalline pentaacetates of specific rotation $+117.4^{\circ}$ and $+34.7^{\circ}$, respectively. By partial deacetylation of the acetates there were obtained two crystalline $N$-acetyl derivatives, namely, $N$-acetyl- $\alpha$-D-galactopyranosylamine, $[\alpha]_{D}^{20}+194.9^{\circ}$, m. p. $179^{\circ}$ to $180^{\circ} \mathrm{C}$, and $N$-acetyl- $\beta$-D-galactopyranosylamine $[\alpha]_{D}^{20}+9.8^{\circ}$, m. p. $233^{\circ} \mathrm{C}$. The $N$-acetyl derivatives, by periodate oxidation and study of the resultant dialdehydes, 
were shown to be an alpha-beta pyranose pair. Since a shift in ring structure seems improbable, the corresponding pentaacetates and the parent galactosylamines can be tentatively classified also as pyranoses.

The mutarotation and hydrolysis of the two galactosylamines were studied and found to be in harmony with the mechanisms previously advanced by us. The mutarotation constant for $\alpha$-D-galactosylamine ammonia complex at various $\mathrm{pH}$ levels may be expressed by the following equation:

$$
k_{m}=0.004+6 \times 10^{6}\left[H^{+}\right]+0.4\left[\mathrm{OH}^{-}\right] .
$$

The hydrolysis of D-galactosylamine, like the previously studied hydrolysis of L-arabinosylamine, takes place rapidly only in a limited $\mathrm{pH}$ range. The maximum rate is at $\mathrm{pH} 4.8$, and the rate constant is given by the expression

$$
k_{\text {hydrol }}=\frac{1}{22.5+616 \times 10^{4}\left[H^{+}\right]+1.55 \times 10^{9}\left[\mathrm{OH}^{-}\right]} .
$$

The work establishes experimentally for the first time the existence of the alpha and beta modifications of a glycosylamine. The existence of these compounds supports the interpretation of the mutarotation of the glycosylamines as consisting of the interconversion of alpha and beta isomers. The optical rotations of the new compounds and of the products of periodate oxidation can be used in various ways for the assignment of structures to compounds in this field.

The authors greatly appreciate the assistance of Nancy B. Holt, who made most of the optical measurements and assisted in other experimental work and of Rolf A. Paulson, who analyzed the compounds reported.

\section{References}

[1] H. S. Isbell and H. L. Frush, J. Research NBS 46, 132 (1951) RP 2186.

[2] C. A. Lobry de Bruyn and F. H. Van Leent, Rec. trav. Pays-Bas 14, 134 (1895).

[3] C. A. Lobry de Bruyn and F. H. Van Leent, Rec. trav. Pays-Bas 15, 81 (1896).

[4] J. N. Brönsted and E. A. Guggenheim, J. Am. Chem. Soc. 49, 2554 (1927)

[5] C. Niemann and J. T. Hays, J. Am. Chem. Soc. 62, 2960 (1940).

[6] S. Rapoport, Biochem. Z. 289, 406 (1937).

[7] H. S. Isbell, BS J. Research 5, 1179 (1930) RP 253.

Washington, February 26, 1951 